\title{
Editorial preface
}

\author{
Ronald L. Hall
}

Published online: 3 February 2013

(C) Springer Science+Business Media Dordrecht 2013

In this issue, we turn our attention to the recent upsurge of interest amongst philosophers of religion and in the general culture (at least in the west) in alternatives to traditional theism. Recent books on the subject of atheism, especially Dawkins' book, The God Delusion and Hitchens' book, God is not Great, have become best sellers in the US. In this wake of this interest, philosophers of religion and religious believers in general have taken notice of what our lead article calls, this "New Atheism," or at least this new interest in it, or versions of it, and the stir it has provoked.

As one might expect, traditional theism has defended itself against the claims of the new atheism. Andrew Johnson however charges that some (or most) of these defenses of traditional theism, that is, these attacks on the new atheism, have been misplaced, or just down right fallacious, and perhaps even immoral. In response, he offers his own apology (defense) for this new atheism that blunts many of its theistic critics. At the same time, Johnson does not foreclose the possibility of a more plausible theistic critique of the new atheism, and hence seems open to a more plausible apology for theism (in some form).

Any discussion of atheism will not be far removed from Nietzsche's announcement of the "death of God." But as Robert Gall notes in our second essay, the existential force of this "death" has most often not been fully digested. He argues that most philosophers in the Continental tradition have followed Hegel's idea of the death of God more so than Nietzsche's more radical declaration. From Hegel's time right down to our own modern and post-modern updates of "God's death," it has gone unnoticed that the divine obituary carried an implicit birth announcement: the welcome death of one concept of God (say the God of the philosophers) made way for a better concept, for example, the God of Abraham, Isaac and Jacob. One exception to this

R. L. Hall ( $\varangle)$

Stetson University, DeLand, USA

e-mail: ronhall@ stetson.edu 
Hegelian interpretation of God's death is found in Heidegger, who came closest to seeing the radical nature of Nietzsche existential confrontation with God's absence. What Heidegger saw was that Nietzsche was not simply proclaiming that we need a new conception of God, but that any conception of God must be continually questioned. Gall agrees: if we are to come to ourselves, we do not need a renewal of faith in God as a new way of settling things; rather we need to find the faith to confront the questions and doubts that tragedy registers in us - those questions and doubts that define our concrete existence.

Simon Glendinning has provided a typology of atheism that expands the usual contrast between religious theism and atheism. On his tripartite scheme there are three cultures of atheism. The first form of atheism is found within religious theism. This culture of atheism is that part of religious faith that is confronted by and must grapple with serious doubts about the existence of God, and the experience of the absence of God in the world. Religious faith has to make its way in view of that atheistic experience. This form of atheism stands in stark contrast to what Glendinning calls modern atheism. This is the atheism of in-your-face rudeness. This is the atheism of Hitchens, Dawkins and Dennett and it is focused on the epistemic standing of our beliefs in contrast to the existential focus of the atheism within religion. For modern atheism, the issue is clear: atheism and theism are simply contradictory belief systems, and in the market place of conflicting beliefs the modern atheist makes the pitch that theistic beliefs are rationally untenable and hopefully will go the way of superstition. But there is a third culture of atheism. Glendinning calls this the culture of a-theism. He finds it best represented in the thought of Wittgenstein and Derrida. This is a culture that Glendinning finds on the rise in Europe. The a-theist, like the modern atheist, does not have religious faith. However, unlike the modern atheist, the a-theist does not make the reasonableness of religious beliefs a question of science, and so the culture is characterised by the absence of antagonistic rudeness. This sort of position is often conceived as expressing religious indifference, but Glendinning invites an alternative way of understanding it - as resisting both the theism of the traditional believer and the scientism of the modern atheist. Glendinning speculates that this culture of a-theism will continue to grow, especially when modern atheism is finally seen as "nothing more than a scientistic pose."

Our last essay continues to reflect on the resurgence of Nietzsche's "death of God" theme that began in full force in the 60's with Altizer and continues today with a great many other secularized approaches to theology that focus on immanence. And as we might have expected, reactions to this secular approach have arisen (starting in England at Cambridge) under the banner of "Radical Orthodoxy." This movement counters the secular focus on immanence with a reassertion of the theological importance of transcendence. Rather than defending one side or the other in these rather shrill debates, William Franke sets out to show that even though both radical secular theology and radical orthodoxy profess to reject negative theology, both sides share what he calls a common, but unacknowledged, apophatic turn of thought. Or as we might say, both are rooted (in different ways) in a philosophy of the unsayable, the unknowable. As I see it, this essay is itself radical, but not only insofar as it shows unacknowledged commonalities between radical secularism and radical orthodoxy but also because it suggests the fruitfulness of thinking of other approaches to the philosophy of reli- 
gion in terms of this apophatic turn of thought. I think, for example, of the work of D.Z. Philips who took so much from Wittgenstein's idea of passing over in silence what cannot be said, of the importance of the mystical, and so forth. Indeed, in one of Philips' last essays, "An Audience for Philosophy of Religion" he claims that a proper and often neglected task for the philosopher of religion is the task of acknowledging the unknowness of God. 